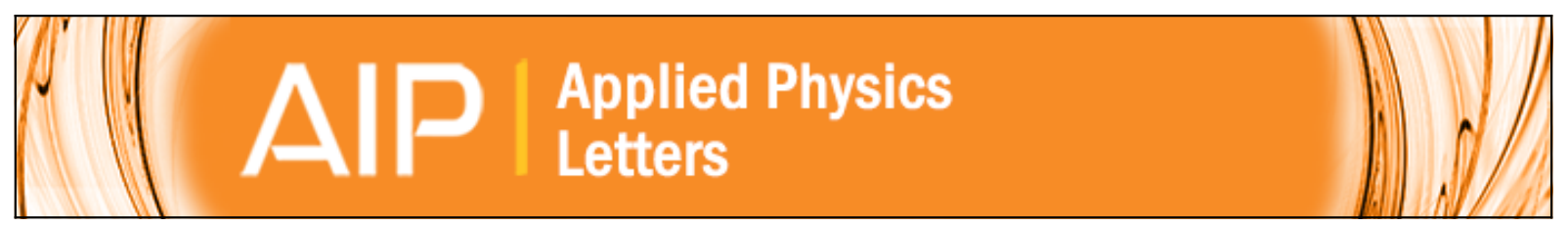

\title{
Upgraded metallurgical-grade silicon solar cells with efficiency above $\mathbf{2 0} \%$
}

P. Zheng, F. E. Rougieux, C. Samundsett, Xinbo Yang, Yimao Wan, J. Degoulange, R. Einhaus, P. Rivat, and

D. Macdonald

Citation: Applied Physics Letters 108, 122103 (2016); doi: 10.1063/1.4944788

View online: http://dx.doi.org/10.1063/1.4944788

View Table of Contents: http://scitation.aip.org/content/aip/journal/apl/108/12?ver=pdfcov

Published by the AIP Publishing

\section{Articles you may be interested in}

Synchrotron-based analysis of chromium distributions in multicrystalline silicon for solar cells

Appl. Phys. Lett. 106, 202104 (2015); 10.1063/1.4921619

Effect of oxygen ambient during phosphorous diffusion on silicon solar cell

J. Renewable Sustainable Energy 4, 033105 (2012); 10.1063/1.4717513

Direct comparison of boron, phosphorus, and aluminum gettering of iron in crystalline silicon

J. Appl. Phys. 109, 073521 (2011); 10.1063/1.3569890

Effect of compensation and of metallic impurities on the electrical properties of Cz-grown solar grade silicon J. Appl. Phys. 104, 104507 (2008); 10.1063/1.3021300

High-efficiency screen-printed belt co-fired solar cells on cast multicrystalline silicon Appl. Phys. Lett. 86, 054103 (2005); 10.1063/1.1855429

\section{Pure Metals • Ceramics} Alloys • Polymers in dozens of forms
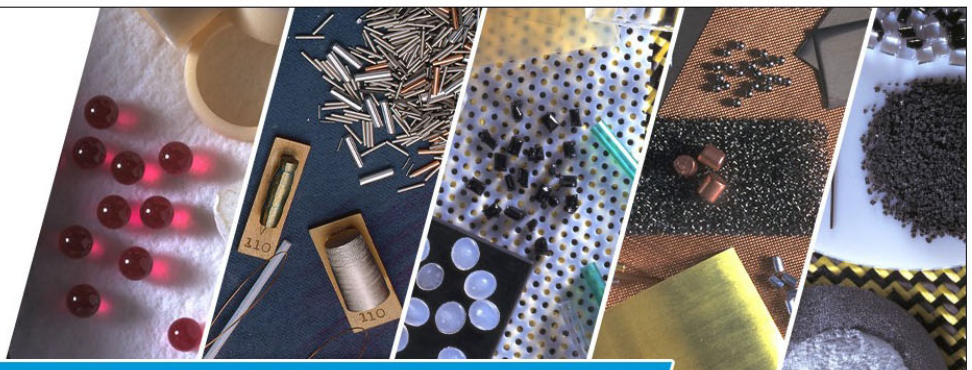


\title{
Upgraded metallurgical-grade silicon solar cells with efficiency above $\mathbf{2 0} \%$
}

\author{
P. Zheng, ${ }^{1}$ F. E. Rougieux, ${ }^{1}$ C. Samundsett, ${ }^{1}$ Xinbo Yang, ${ }^{1}$ Yimao Wan, ${ }^{1}$ J. Degoulange,${ }^{2}$ \\ R. Einhaus, ${ }^{2}$ P. Rivat, ${ }^{3}$ and D. Macdonald ${ }^{1}$ \\ ${ }^{1}$ Research School of Engineering, College of Engineering and Computer Science, The Australian National \\ University, Canberra, Australian Capital Territory 2601, Australia \\ ${ }^{2}$ Apollon Solar, 66 Cours Charlemagne, Lyon 69002, France \\ ${ }^{3}$ FerroPem, 517 Avenue de la Boisse, Chambery Cedex 73025, France
}

(Received 4 January 2016; accepted 13 March 2016; published online 22 March 2016)

\begin{abstract}
We present solar cells fabricated with $n$-type Czochralski-silicon wafers grown with strongly compensated $100 \%$ upgraded metallurgical-grade feedstock, with efficiencies above $20 \%$. The cells have a passivated boron-diffused front surface, and a rear locally phosphorus-diffused structure fabricated using an etch-back process. The local heavy phosphorus diffusion on the rear helps to maintain a high bulk lifetime in the substrates via phosphorus gettering, whilst also reducing recombination under the rear-side metal contacts. The independently measured results yield a peak efficiency of $20.9 \%$ for the best upgraded metallurgical-grade silicon cell and $21.9 \%$ for a control device made with electronic-grade float-zone silicon. The presence of boron-oxygen related defects in the cells is also investigated, and we confirm that these defects can be partially deactivated permanently by annealing under illumination. (C) 2016 AIP Publishing LLC.
\end{abstract}

[http://dx.doi.org/10.1063/1.4944788]

Upgraded Metallurgical-Grade (UMG) silicon has raised interest as a low cost alternative material for high efficiency silicon solar cells. ${ }^{1-7}$ UMG silicon feedstock is purified using a liquid phase purification process. As a result, it contains more impurities, especially shallow acceptors and donors (B, $\mathrm{Al}$, and $\mathrm{P}$ ), and the minority carrier lifetime is usually lower in the as-grown state. In addition, due to dopant compensation, the carrier mobility is reduced, and the presence of boron leads to the formation of the boron-oxygen (BO) defect, even in $n$-type compensated UMG silicon wafers. ${ }^{8-10}$ Recent improvements in the UMG purification process have led to an improvement in feedstock quality. In this paper, we present a high efficiency (20.9\%) silicon cell based on $100 \%$ solargrade feedstock, using $n$-type Czochralski-grown $(\mathrm{Cz})$ wafers.

With the advent of higher quality UMG material, ${ }^{11}$ reported cell efficiencies using this material have improved significantly in the recent years. For $p$-type UMG silicon solar cells, in 2010, an efficiency of $17 \%$ was reported for multi-crystalline silicon (mc-Si) solar cells, with an average batch efficiency of $16.4 \%$. An efficiency of $17.6 \%$ was also achieved for a $p$-type monocrystalline UMG silicon solar cell, with an average batch efficiency of $17.4 \%$ using the same process. ${ }^{4}$ In 2011, comparable cell efficiencies were achieved for $p$-type mc-Si UMG solar cells and cells made with standard electronic-grade feedstock, of $18.35 \%$ and $18.45 \%$, respectively. ${ }^{5}$ By switching from $p$-type to $n$-type UMG, in 2012, 19\% efficiency was achieved using $100 \%$ UMG $\mathrm{Cz}$ silicon with a heterojunction device. ${ }^{6}$ This was then followed by a $19 \% n$-type UMG Cz homojunction cell one year later. ${ }^{7}$ Recently, Rougieux et al. ${ }^{12}$ reported a $19.8 \%$ efficient Passivated Emitter Rear Totally diffused (PERT) cell using $100 \%$ UMG $n$-type $\mathrm{Cz}$.

In this paper, we present an $n$-type $\mathrm{Cz}$ cell with an efficiency of $20.96 \%$ using $100 \%$ UMG feedstock, and describe the optimised device design and the impact of boron-oxygen-related defects on device performance.
In this study, we have used two different types of $n$-type monocrystalline silicon wafers. The first type was from a $9.5 \mathrm{~kg}$ ingot with a diameter of 6 inch, grown with $100 \%$ UMG silicon feedstock without adding electronic grade (EG) polysilicon feedstock using the Czochralski process. The second type was from a Float-Zone (FZ) grown ingot using standard EG silicon feedstock. The UMG feedstock was produced by FerroPem in the framework of the PHOTOSIL project. The wafers had resistivities of $4 \Omega \mathrm{cm}$ (solidified fraction $\left.f_{s}=20 \%\right)$ for the UMG material and $1 \Omega \mathrm{cm}$ for the EG wafers. The doping density of both phosphorus and boron was measured by Secondary Ion Mass Spectrometry (SIMS) analysis, showing that the UMG wafers had a boron concentration of $[\mathrm{B}]=1.27 \times 10^{16} \mathrm{~cm}^{-3}$ and a phosphorus concentration of $[\mathrm{P}]=1.42 \times 10^{16} \mathrm{~cm}^{-3}$, which results in a net doping of $n_{0}=1.4 \times 10^{15} \mathrm{~cm}^{-3}$. The oxygen and carbon concentrations of the UMG wafers were $[\mathrm{O}]=6.6 \times 10^{17} \mathrm{~cm}^{-3}$ and $[C]=6.1 \times 10^{16} \mathrm{~cm}^{-3}$, respectively. The concentrations of metallic impurities were below the detection limit of Inductively Coupled Plasma Mass Spectrometry (ICPMS). The EG wafers were non-compensated and had a majority carrier concentration of $n_{0}=[\mathrm{P}]=4.8 \times 10^{15} \mathrm{~cm}^{-3}$, as determined by the dark conductance measurements.

The cell structure used in this study is a Passivated Emitter Rear Locally diffused (PERL) solar cell structure, ${ }^{13}$ specially adapted to maintain a high carrier lifetime in the UMG material, and is represented in Figure 1. The cells were $2 \times 2 \mathrm{~cm}^{2}$ in size. The front surface was random pyramid textured using tetramethylammonium hydroxide (TMAH) and isopropyl alcohol (IPA) solution. The emitter was formed by full-area boron diffusion with a sheet resistance of approximately $120 \Omega / \square$ at $940^{\circ} \mathrm{C}$ of 17 min deposition in an atmosphere of mixture of $\mathrm{O}_{2}, \mathrm{~N}_{2}$, and $\mathrm{BBr}_{3}$. The rear localized diffusions were $75 \mu \mathrm{m}$ diameter dots with a hexagonal pitch of $300 \mu \mathrm{m}$, which was formed by a full-area phosphorous diffusion and etch back in TMAH solution. The sheet resistance 


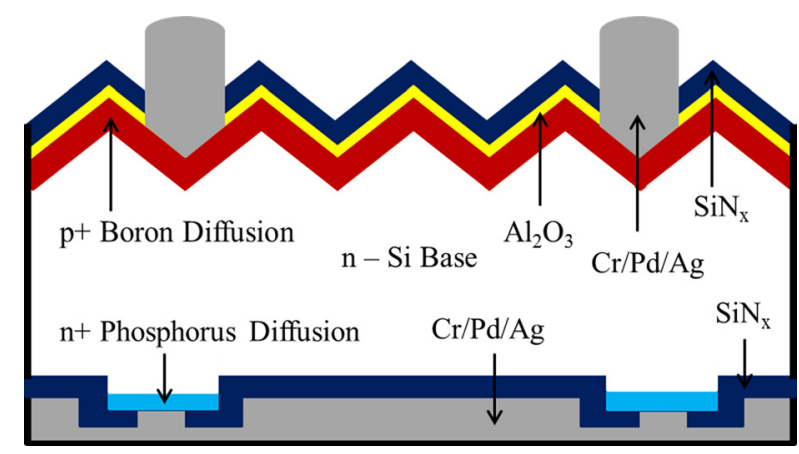

FIG. 1. Schematic diagram of $n$-type UMG silicon solar cell with full front boron diffusion and rear etch-back localized phosphorus diffusion, $\mathrm{Al}_{2} \mathrm{O}_{3} /$ $\mathrm{SiN}_{\mathrm{x}}$ stack at the front and $\mathrm{SiN}_{\mathrm{x}}$ at the rear side and with $\mathrm{Cr} / \mathrm{Pd} / \mathrm{Ag}$ stacks for both the front and rear metallization.

was approximately $70 \Omega / \square$ at $790^{\circ} \mathrm{C}$ of 25 min deposition in an atmosphere of mixture of $\mathrm{O}_{2}, \mathrm{~N}_{2}$, and $\mathrm{POCl}_{3}$. The front surface passivation layer was an $\mathrm{Al}_{2} \mathrm{O}_{3} / \mathrm{SiN}_{\mathrm{x}}$ stack, and the rear passivation layer was a single $\mathrm{SiN}_{\mathrm{x}}$ film. $\mathrm{The} \mathrm{Al}_{2} \mathrm{O}_{3}$ film was deposited by Atomic Layer Deposition (ALD) at $175^{\circ} \mathrm{C}$ and then activated at $400^{\circ} \mathrm{C}$ and $\mathrm{SiN}_{\mathrm{x}}$ by Plasma-Enhanced Chemical Vapour Deposition (PECVD) at $400^{\circ} \mathrm{C}$. Front and rear contact areas were defined by photolithography followed by the thermal evaporation of $\mathrm{Cr} / \mathrm{Pd} / \mathrm{Ag}$ stacks with subsequent Ag electroplating of the front fingers to increase the finger thickness. The contacts were sintered at $350^{\circ} \mathrm{C}$ for $30 \mathrm{~min}$ in forming gas (FGA). The front finger contact openings were $10 \mu \mathrm{m}$ wide prior to plating, with a spacing of $1.3 \mathrm{~mm}$. The rear contact openings were $30 \mu \mathrm{m}$ in diameter and had the same pitch as the localized diffusion.

In order to measure the recombination parameter $J_{0}$ of the front textured boron diffusion, we used $100 \Omega \mathrm{cm} n$-type control wafers. To measure the $J_{0}$ for the un-diffused rear side passivated with $\mathrm{SiN}_{\mathrm{x}}$, we used sister wafers to those used for cells. Dark IV measurements were performed using a Keithley 2400 source meter to extract the shunt resistance $\left(R_{s h}\right){ }^{14}$ The contact resistivity $\left(\rho_{c}\right)$ was measured using Transfer Length Method (TLM) measurements. ${ }^{15}$ Suns- $V_{\text {oc }}$ measurements ${ }^{16}$ were performed to evaluate the lumped series resistance $\left(R_{S}\right)$ at the maximum power point. ${ }^{17}$
In order to investigate the impact of high temperature processing (boron and phosphorus diffusion) on the minority carrier lifetime of the UMG wafers, we used sister wafers $\left(f_{s}=23 \%\right)$ to the cell wafers $\left(f_{s}=20 \%\right)$. The FZ EG control wafers from the same ingot as the EG cell of resistivity $1 \Omega$ $\mathrm{cm}$ were also included. The samples were TMAH etched after processing to remove the boron and phosphorus diffusions, and then passivated by PECVD $\mathrm{SiN}_{\mathrm{x}}$. The bulk lifetimes of both the samples before and after processing are shown in Figure 2. The UMG sample had an initial as-cut lifetime above $1 \mathrm{~ms}$, while the EG FZ control wafer had an initial ascut lifetime of several milliseconds. The samples then underwent boron diffusion. The bulk lifetimes degraded to around $100 \mu$ s and $200 \mu$ s after boron diffusion for the UMG and FZ wafers, respectively. The reduction of the bulk lifetime after boron diffusion in both the UMG and FZ controls indicates some process contamination. In addition to the process contamination, the lower lifetime in the UMG wafers indicates the additional presence of residual impurities in these wafers that are activated during the boron diffusion.

After the boron diffusion, the samples were then subjected to phosphorus diffusion, as required to allow ohmic contact to the rear side of the devices. It can be seen from Figure 2 that the phosphorus diffusion also recovers the bulk lifetime to above $500 \mu$ s for both the wafer types, due to gettering of mobile impurities introduced during the boron diffusion. Note that the diffusion is optimized for cell front diffusion and not for gettering; hence recovery of the lifetime is only partial in these wafers. Therefore, a process with phosphorus gettering after boron diffusion is important for the UMG wafers. To maintain a high bulk lifetime in the UMG cells, relatively heavy and full area phosphorus diffusion was chosen for the cell process. However, a heavy phosphorus diffusion will significantly increase recombination on the non-metallised portion of the rear side, for a device with a full rear-side diffusion, such as the Passivated Emitter and Rear Totally diffused (PERT) cells we have reported previously on similar material. ${ }^{12}$ Therefore, a PERL structure was selected to minimise the area of the diffused regions to achieve high efficiency UMG solar cells. Crucially, the

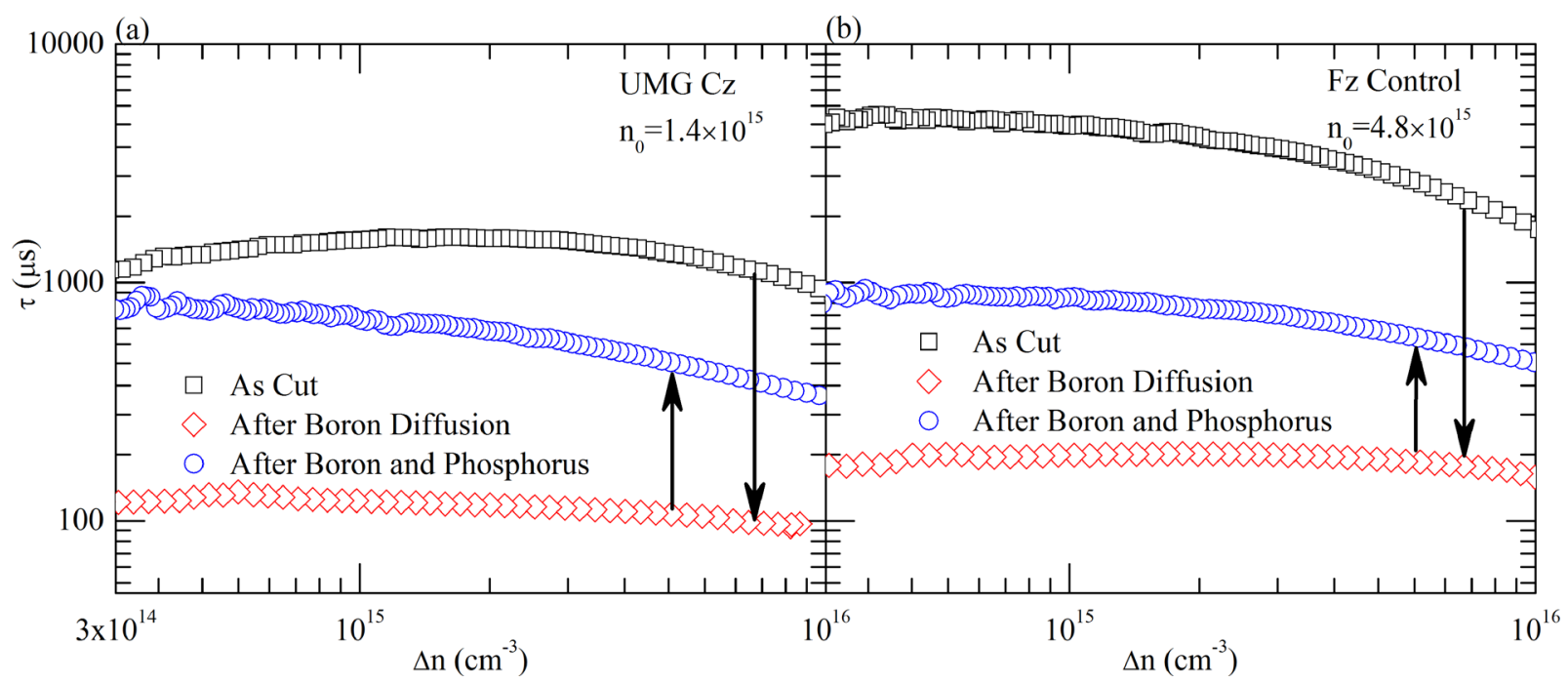

FIG. 2. Injection dependent minority carrier bulk lifetime (a) $n$-type FZ $1 \Omega \mathrm{cm}$ control wafer and (b) $n$-type UMG Cz silicon wafers in the as-cut state, after boron diffusion, and after both boron and phosphorus diffusions. 


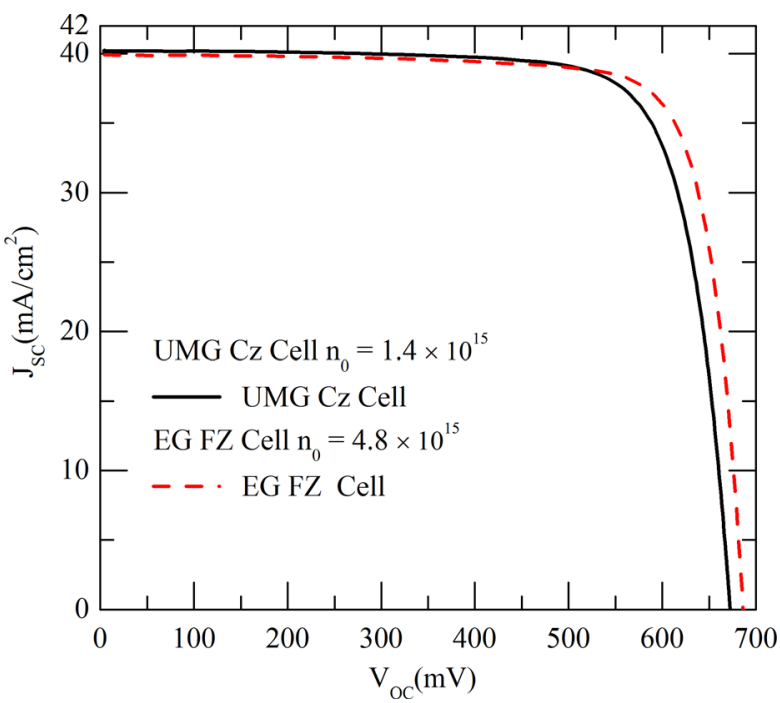

FIG. 3. Independent illuminated IV measurements of the best $n$-type UMG $\mathrm{Cz}$ and EG FZ cells, measured at Fraunhofer CalLab.

TABLE I. Dopant concentration and type, net doping $n_{0}$, and thickness $W$ of the UMG Cz and EG FZ cells.

\begin{tabular}{lcccc}
\hline \hline Cell & {$[\mathrm{P}]\left(\mathrm{cm}^{-3}\right)$} & {$[\mathrm{B}]\left(\mathrm{cm}^{-3}\right)$} & $\mathrm{n}_{0}\left(\mathrm{~cm}^{-3}\right)$ & $\mathrm{W}(\mu \mathrm{m})$ \\
\hline UMG Cz & $1.42 \times 10^{16}$ & $1.27 \times 10^{16}$ & $1.4 \times 10^{15}$ & 150 \\
EG FZ & $4.8 \times 10^{15}$ & $\cdots$ & $4.8 \times 10^{15}$ & 170 \\
\hline \hline
\end{tabular}

localization of the diffusion at the rear side is achieved by an-etch back process, instead of being diffused locally into the contact area, in order to maintain a full-area gettering effect. In addition, the heavy local phosphorus diffusion has the benefit of reducing recombination under the metal contacts, in comparison to the lighter diffusions usually required for an efficient PERT device.

Independent measurements of the illuminated currentvoltage characteristics at Fraunhofer CalLab confirm an efficiency of $20.96 \%$ and $21.91 \%$ for the best $n$-type UMG Cz cell and the best EG FZ cell, respectively. The IV curves are plotted in Figure 3. The thickness, dopant concentrations, and net doping $n_{0}\left(n_{0}=[\mathrm{P}]-[\mathrm{B}]\right.$ for the UMG material $)$ of the cells are shown in Table I. Details of the extracted cell parameters are shown in Table II. Device parameters measured on the control wafers are reported in Table III.

The External Quantum Efficiency (EQE) and reflectance measurements for the best cells are shown in Figure 4. These reveal a slightly higher EQE for the UMG cell in the wavelength range from 300 to $900 \mathrm{~nm}$, especially in the range from $300 \mathrm{~nm}$ to $600 \mathrm{~nm}$. This difference results from a slight difference in the random texturing at the front surface and minor variations in the thickness of $\mathrm{SiN}_{\mathrm{x}}$ capping layer on the front surface. To confirm this, the reflectance of both the cells was measured. Figure 4 shows the reflectance measurements for
TABLE III. Cell parameters measured on the control wafers for both front and rear sides of the cells.

\begin{tabular}{lcc}
\hline \hline Side & Properties & Value \\
\hline Front & Sheet resistance & $120 \Omega / \square$ \\
& $R_{\text {contact }}$ & $0.06 \mathrm{~m} \Omega \mathrm{cm}^{2}$ \\
& $J_{O \text {-passivated }}$ & $45 \mathrm{fA} / \mathrm{cm}^{2}$ \\
Rear & Sheet resistance & $70 \Omega / \square$ \\
& $R_{\text {contact }}$ & $0.024 \mathrm{~m} \Omega \mathrm{cm}^{2}$ \\
& $J_{O \text {-passivated }}$ & $3 \mathrm{fA} / \mathrm{cm}^{2}$ \\
\hline \hline
\end{tabular}

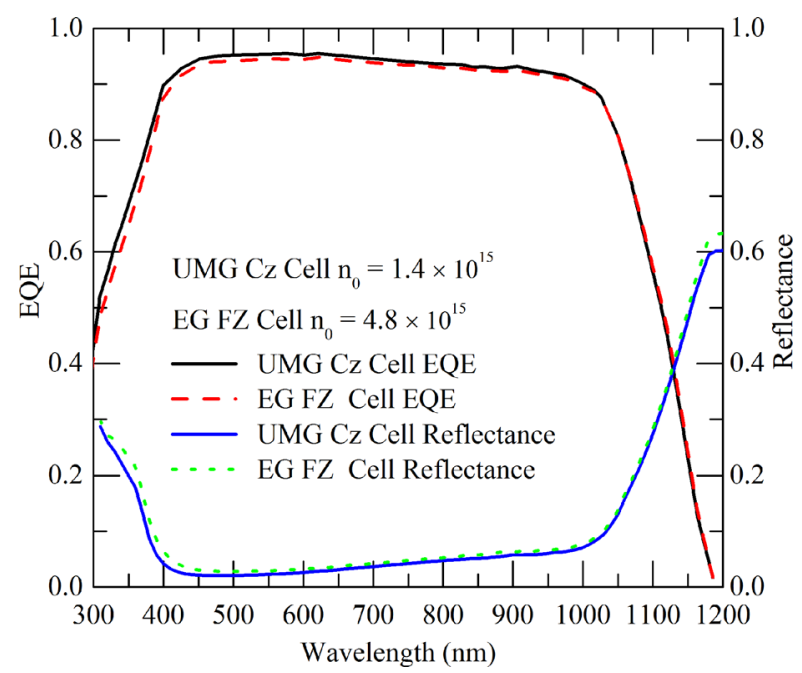

FIG. 4. EQE measurement of the best $n$-type UMG Cz and EG FZ cells (measured at Fraunhofer CalLab) also shown is the Reflectance for both cells.

both the UMG and FZ cells. It confirms that the reflectance for FZ cell is slightly higher than that for UMG cell in the range from $300 \mathrm{~nm}$ up to $900 \mathrm{~nm}$. Of particular note is the fact that the UMG and FZ cells are almost identical in their EQE in the long wavelength range between $900 \mathrm{~nm}$ and $1200 \mathrm{~nm}$. This indicates that the minority carrier diffusion length is significantly larger than the wafer thickness for both the UMG and FZ cells, despite the expected impact of the strong dopant compensation on the carrier mobilities in the UMG material. Based on the carrier lifetimes in Figure 2, the minority carrier diffusion lengths for the UMG and FZ cells are estimated to be $695 \mu \mathrm{m}$ and $1018 \mu \mathrm{m}$, with the minority carrier mobilities estimated using Schindler's model ${ }^{18}$ of $372 \mathrm{~cm}^{2} \mathrm{~V}^{-1} \mathrm{~s}^{-1}$ and $399 \mathrm{~cm}^{2} \mathrm{~V}^{-1} \mathrm{~s}^{-1}$. These diffusion lengths are more than three times the device thickness, resulting in almost complete carrier collection at the front junction.

The impact of the BO related-defect has been extensively studied in $p$-type boron doped and compensated silicon, as well as in $n$-type compensated silicon for several years. ${ }^{8,10,19,20}$ Recently, the focus has moved to the permanent deactivation of the $\mathrm{BO}$ defects ${ }^{21-25}$ by annealing under

TABLE II. Extracted parameters from the illuminated IV, dark IV, and Suns- $\mathrm{V}_{\mathrm{oc}}$ characteristics.

\begin{tabular}{lccccccccc}
\hline \hline Cell & $\mathrm{J}_{\mathrm{sc}}\left(\mathrm{mA} \mathrm{cm}^{-2}\right)$ & $\mathrm{V}_{\mathrm{oc}}(\mathrm{mV})$ & $\mathrm{J}_{\mathrm{mpp}}\left(\mathrm{mA} \mathrm{cm}^{-2}\right)$ & $\mathrm{V}_{\mathrm{mpp}}(\mathrm{mV})$ & $\mathrm{FF}(\%)$ & $\eta(\%)$ & $\mathrm{R}_{\mathrm{sh}}\left(\Omega \mathrm{cm}^{2}\right)$ & $\mathrm{R}_{\mathrm{s}, \mathrm{mpp}}\left(\Omega \mathrm{cm}^{2}\right)$ & PFF \\
\hline UMG Cz & 40.23 & 672.6 & 37.03 & 566.1 & 77.5 & 20.96 & 8000 & 0.77 & 82.2 \\
EG FZ & 39.89 & 686.2 & 37.03 & 591.7 & 80.1 & 21.91 & 5000 & 0.35 & 81.5 \\
\hline \hline
\end{tabular}




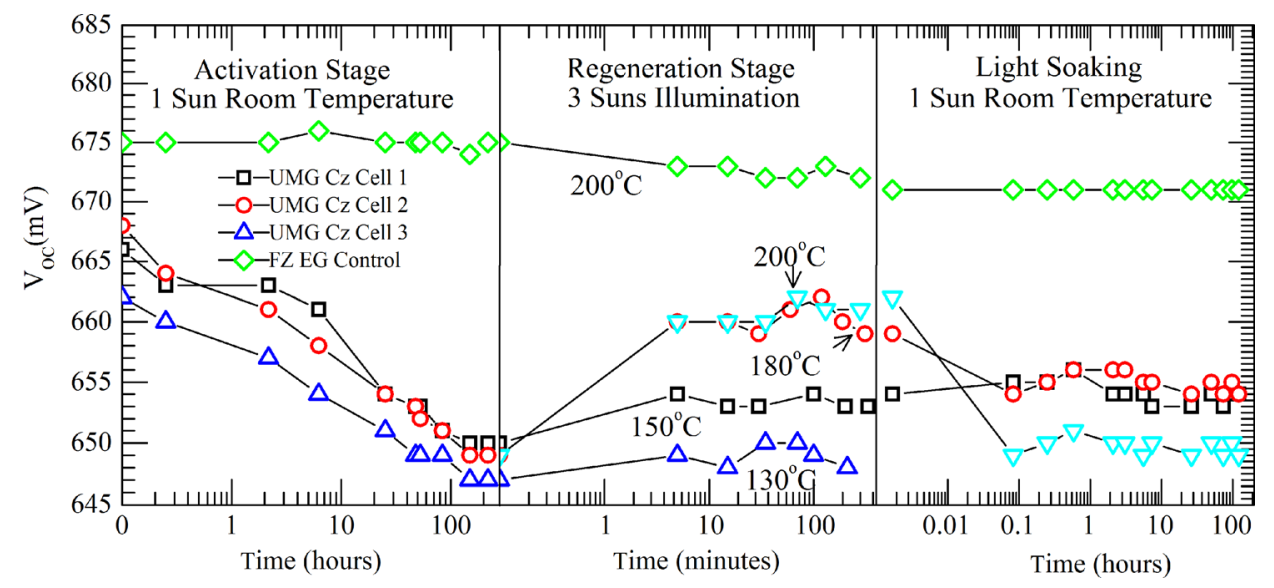

FIG. 5. The $V_{o c}$ evolution due to the boron-oxygen related defect of 3 investigated UMG Cz Cells through 3 different stages: an Activation stage, a Regeneration stage, and a Light Soaking stage (stability test). illumination or bias. In this experiment, the $n$-type PERL UMG solar cells are used to investigate the impact of the BO defect at the cell level. The $V_{o c}$ evolution of the cells is shown in Figure 5. For the defect activation stage, the $V_{o c}$ of the UMG cells degraded by approximately $17 \mathrm{mV}$ over a 200 $\mathrm{h}$ illumination at an intensity of 1 sun, while the FZ control cell did not experience any degradation, as expected. The regeneration was then performed at four different temperatures ranging from $130^{\circ} \mathrm{C}$ to $200^{\circ} \mathrm{C}$ under an illumination intensity of 3 suns. The $V_{o c}$ improvements increased with the increasing temperature. The cell annealed at $130{ }^{\circ} \mathrm{C}$ (Cell 3) did not see significant improvement. However, Cell 3 showed a fast improvement during subsequent annealing at $200{ }^{\circ} \mathrm{C}$. The same control cell was used for all the processes and only experienced slight degradation during the final $200^{\circ} \mathrm{C}$ annealing. The stability of the regenerated cells was then tested under 1 sun light intensity over $200 \mathrm{~h}$. Cell 3, which was regenerated at $200 \mathrm{C}$, showed a fast degradation back to the level of the degraded cells under illumination. Cell 1 , which was regenerated at $150^{\circ} \mathrm{C}$, did not show any degradation and remained at approximately $655 \mathrm{mV}$. Cell 2 degraded slightly and saturated at the same level as Cell 1.

Munzer $^{21}$ and Herguth et al. ${ }^{22}$ reported regeneration of the $\mathrm{BO}$ defect in $p$-type silicon solar cells at 50 to $75^{\circ} \mathrm{C}$, and showed that the regenerated cells had similar $V_{o c}$ and efficiencies as the cells before degradation. The cells were stable under illumination of 1 sun intensity over $200 \mathrm{~h}$. However, from Figure 5, it can be seen that the $V_{o c}$ of the regenerated cells cannot be recovered to the initial value. Niewelt et al. ${ }^{23}$ used $n$-type compensated wafers with similar oxygen, boron, and phosphorus concentrations for a regeneration experiment, and showed on lifetime structures that the regeneration cannot recover the bulk lifetime to the initial level with nonoptimized curing conditions. The non-optimized temperature and the illumination intensity could therefore explain the partial recovery of $V_{o c}$ in this study. The slight degradation of Cell 2 and complete degradation of Cell 3 during the stability test could also be related to the non-optimized curing conditions. As suggested by Wilking et al., ${ }^{24}$ when starting from a fully degraded state, the reactions creating the annealed state and permanently deactivated state of the BO defect are competing reactions. Their kinetics depends on the temperature. If the temperature is too high, the kinetics of the reaction creating the annealed state will be faster than the reaction producing the permanently deactivated state.
Hence, most of the $\mathrm{BO}$ defect will transform into the annealed state rather than the permanently deactivated state. This is likely to be the reason that Cells 2 and 3 degraded during the final stability test. The reason for the much faster degradation rate of Cell 3 during the light soaking after permanent deactivation compared to the initial light soaking is still unclear. Various authors have proposed physical explanations of the regeneration process. Voronkov et $a l^{26}$ suggested that the regeneration process was due to the loss of interstitial boron to boron nano-precipitates during simultaneous annealing and illumination. Upon subsequent illumination, no interstitial boron is present and therefore no recombination active $\mathrm{BO}$ can form. Hallam et al. ${ }^{25}$ and Munzer ${ }^{21}$ proposed that the regeneration is caused by the hydrogenation of $\mathrm{BO}$ defects and controlled by the charge state of hydrogen, which is strongly related to the temperature and illumination intensity, as also proposed by Sun et al. ${ }^{27}$

In conclusion, we have presented silicon solar cells based on 100\% UMG $\mathrm{Cz}$ wafers with efficiencies above $20 \%$, and only slightly lower than the efficiencies achieved for control FZ EG cells fabricated using the same process. This shows that with an optimised fabrication process, the bulk lifetime and minority carrier diffusion length are not strongly limiting factors for UMG material to achieve high efficiency devices. In addition, we have shown that BO defects still affect the efficiency of $n$-type UMG $\mathrm{Cz}$ solar cells. However, they can be partially deactivated with annealing under illumination. With an optimized illumination intensity and temperature, a more complete deactivation of this defect should be possible.

This work was supported by the Australian Renewable Energy Agency (ARENA) through the Australian Center for Advanced Photovoltaics (ACAP), Project RND009, and their Postdoctoral Fellowships program. D.M. acknowledges the support from the Australian Research Council through the Future Fellowships program.

\footnotetext{
${ }^{1}$ N. Yuge, H. Baba, Y. Sakaguchi, K. Nishikawa, H. Terashima, and F. Aratani, Sol. Energy Mater. Sol. Cells 34(1), 243 (1994).

${ }^{2} \mathrm{~K}$. Ounadjela and A. Bloss, "New metallization technique for $6 \mathrm{MW}$ pilot production of multicrystalline solar cells using upgraded metallurgical grade silicon," NREL Technical Report No. NREL/SR-520-48591, CaliSolar, Inc., Sunnyvale, 2010.

${ }^{3}$ D. Kohle, B. Raabe, S. Braun, S. Seren, and G. Hahn, "Upgraded metallurgical grade silicon solar cells: A detailed material analysis," in Proceeding
} 
of the 24th European Photovoltaic Solar Energy Conference, Hamburg, Germany (2009), pp. 1758-1761.

${ }^{4}$ J. Kraiem, B. Drevet, F. Cocco, N. Enjalbert, S. Dubois, D. Camel, D. Grosset-Bourbange, D. Pelletier, T. Margaria, and R. Einhaus, "High performance solar cells made from $100 \%$ UMG silicon obtained via the PHOTOSIL process," in Proceeding of the 35th IEEE Photovoltaic Specialists Conference (PVSC) (2010), pp. 001427-001431.

${ }^{5}$ P. Engelhart, J. Wendt, A. Schulze, C. Klenke, A. Mohr, K. Petter, F. Stenzel, S. Hörnlein, M. Kauert, M. Junghänel, B. Barkenfelt, S. Schmidt, D. Rychtarik, M. Fischer, J. W. Müller, and P. Wawer, Energy Procedia 8, 313 (2011).

${ }^{6}$ R. Einhaus, J. Kraiem, J. Degoulange, O. Nichiporuk, M. Forster, P. Papet, Y. Andrault, D. Grosset-Bourbange, and F. Cocco, "19\% efficiency heterojunction solar cells on $\mathrm{Cz}$ wafers from non-blended upgraded metallurgical silicon," in Proceeding of the 38th IEEE Photovoltaic Specialists Conference (PVSC) (2012), pp. 003234-003237.

${ }^{7}$ Y. Schiele, S. Wilking, F. Book, T. Wiedenmann, and G. Hahn, Energy Procedia 38, 459 (2013).

${ }^{8}$ T. Schutz-Kuchly, J. Veirman, S. Dubois, and D. R. Heslinga, Appl. Phys. Lett. 96(9), 093505 (2010).

${ }^{9}$ F. E. Rougieux, M. Forster, D. Macdonald, A. Cuevas, B. Lim, and J. Schmidt, IEEE J. Photovoltaics 1(1), 54 (2011).

${ }^{10}$ F. E. Rougieux, B. Lim, J. Schmidt, M. Forster, D. Macdonald, and A. Cuevas, J. Appl. Phys. 110(6), 063708 (2011).

${ }^{11}$ M. Forster, E. Fourmond, R. Einhaus, H. Lauvray, J. Kraiem, and M. Lemiti, Phys. Status Solidi C 8(3), 678 (2011).

${ }^{12}$ F. Rougieux, C. Samundsett, K. C. Fong, A. Fell, P. Zheng, D. Macdonald, J. Degoulange, R. Einhaus, and M. Forster, Prog. Photovoltaics: Res. Appl. (to be published).

${ }^{13}$ M. A. Green, Silicon Solar Cells: Advanced Principles and Practice (Centre for Photovoltaic Devices and Systems, Sydney, Australia, 1995), pp. 219-220.

${ }^{14}$ I. Martil and G. Gonzalez Diaz, Eur. J. Phys. 13(4), 193 (1992).
${ }^{15}$ D. L. Meier and D. K. Schroder, IEEE Trans. Electron Devices 31(5), 647 (1984).

${ }^{16}$ R. A. Sinton and A. Cuevas, "A quasi-steady-state open-circuit voltage method for solar cell characterization," in Proceeding of the 16th European Photovoltaic Solar Energy Conference, Hamburg, Germany (2000), pp. 1152-1155.

${ }^{17}$ D. Pysch, A. Mette, and S. W. Glunz, Sol. Energy Mater. Sol. Cells 91(18), 1698 (2007).

${ }^{18}$ F. Schindler, M. C. Schubert, A. Kimmerle, J. Broisch, S. Rein, W. Kwapil, and W. Warta, Sol. Energy Mater. and Sol. Cells 106(0), 31 (2012).

${ }^{19}$ K. Bothe and J. Schmidt, J. Appl. Phys. 99(1), 013701 (2006).

${ }^{20}$ D. Macdonald, F. Rougieux, A. Cuevas, B. Lim, J. Schmidt, M. Di Sabatino, and L. J. Geerligs, J. Appl. Phys. 105(9), 093704 (2009).

${ }^{21}$ K. A. Münzer, "Hydrogenated silicon nitride for regeneration of light induced degradation," in Proceeding of the 24th European Photovoltaic Solar Energy Conference Hamburg, Germany (2009), pp. 1558-1561.

${ }^{22}$ A. Herguth, G. Schubert, M. Kaes, and G. Hahn, "A new approach to prevent the negative impact of the metastable defect in boron doped cz silicon solar cells," in Conference Record of the 2006 IEEE 4th World Conference on Photovoltaic Energy Conversion (2006), pp. 940-943.

${ }^{23}$ T. Niewelt, J. Broisch, J. Schön, J. Haunschild, S. Rein, W. Warta, and M. C. Schubert, Energy Procedia 77, 626 (2015).

${ }^{24}$ S. Wilking, M. Forster, A. Herguth, and G. Hahn, Sol. Energy Mater. Sol. Cells 142, 87 (2015).

${ }^{25}$ B. J. Hallam, S. R. Wenham, P. G. Hamer, M. D. Abbott, A. Sugianto, C. E. Chan, A. M. Wenham, M. G. Eadie, and G. Xu, Energy Procedia 38, $561(2013)$

${ }^{26}$ V. V. Voronkov, R. Falster, B. Lim, and J. Schmidt, J. Appl. Phys. 112(11), 113717 (2012).

${ }^{27}$ C. Sun, F. E. Rougieux, and D. Macdonald, J. Appl. Phys. 117(4), 045702 (2015). 